\title{
Psychosocial stress and asthma morbidity
}

\author{
Michael A. Yonas, DrPH, MPH ${ }^{\mathrm{a}}$, Nancy E. Lange, MD, MPH ${ }^{\mathrm{b}, \mathrm{c}}$, and Juan C. Celedón, MD, \\ $\mathrm{DrPH}^{\mathrm{b}, \mathrm{d}}$ \\ aDepartments of Family Medicine and ${ }^{b}$ Pediatrics, University of Pittsburgh, Pittsburgh, PA \\ ${ }^{b}$ Channing Laboratory, Division of Pulmonary and Critical Care Medicine, Department of \\ Medicine, Brigham and Women's Hospital, Boston, MA \\ 'Harvard Medical School, Boston, MA \\ dDivision of Pediatric Pulmonary Medicine, Allergy and Immunology, Children's Hospital of \\ Pittsburgh of the University of Pittsburgh Medical Center, Pittsburgh, PA
}

\begin{abstract}
Purpose of review-The objective of this review is to provide an overview and discussion of recent epidemiologic and mechanistic studies of stress in relation to asthma incidence and morbidity.

Recent findings-Recent findings suggest that stress, whether at the individual- (i.e., epigenetics, perceived stress), family- (i.e., prenatal maternal stress, early life exposure or intimate partner violence) or community- (i.e.., neighborhood violence; neighborhood disadvantage) level influences asthma and asthma morbidity. Key recent findings regarding how psychosocial stress may influence asthma through Post Traumatic Stress Disorder (PTSD), pre-and post-natal maternal/caregiver stress, and community violence and deprivation are highlighted.
\end{abstract}

Summary-New research illustrates the need to further examine, characterize and address the influence of social and environmental factors (i.e., psychological stress) on asthma. Further research and innovative methodologies are needed to characterize the relationship and pathways associated with stress at multiple levels to more fully understand and address asthma morbidity, and to design potential interventions, especially to address persistent disparities in asthma in ethnic minorities and economically disadvantaged communities.

\section{Keywords}

asthma; allergy; stress; psychosocial; cytokines; maternal; violence; community

\section{INTRODUCTION}

Asthma is a major public health problem in the United States [1] and the world [2]. In 2009, the prevalence of current asthma in the U.S. was estimated as $8.2 \%$ (corresponding to 24.6

Copyright $\odot 2012$ Current Opinion in Allergy and Clinical Immunology. Published by Lippincott Williams \& Wilkins.

Corresponding Author: Nancy Lange, MD, MPH, Channing Laboratory and Division of Pulmonary and Critical Care Medicine, Department of Medicine, Brigham and Women's Hospital, 181 Longwood Avenue, Boston, MA 02115, Phone (617) 525-0874, Fax (617) 525-0958, nancy.lange@channing.harvard.edu.

Publisher's Disclaimer: This is a PDF file of an unedited manuscript that has been accepted for publication. As a service to our customers we are providing this early version of the manuscript. The manuscript will undergo copyediting, typesetting, and review of the resulting proof before it is published in its final citable form. Please note that during the production process errors may be discovered which could affect the content, and all legal disclaimers that apply to the journal pertain.

Conflicts of interest: None of the authors have any conflicts of interest to report. 
million affected people) [1]. In this country, members of certain ethnic minority groups, especially Puerto Ricans and African Americans, and the poor share both a disproportionate burden of asthma and increased exposure to psychosocial stress [1,3-7]. There is increasing evidence of a link between stress and asthma whereas psychological stress can affect individual biology, disease progression and disease management throughout the lifespan $[8,9]$. Given this link, there is great interest and a growing body of literature on psychological stress, a potentially modifiable factor, and asthma and asthma morbidity in youth and adults [10] [11].

The purpose of this review is to critically examine recently published literature on psychosocial stress and asthma. An ecological framework has been used to organize and present recent evidence, recognizing that biological, individual, family, and communitylevel psychosocial factors may have individual and synergistic effects on asthma morbidity [12-14]. For ease of exposition, we will separately review the asthma-related literature on psychosocial factors at the individual, family, and community level (Figure 1); and recent interventional studies. We then provide general recommendations for future directions in this field.

\section{STRESS AND ASTHMA AT THE INDIVIDUAL LEVEL}

Inner-city residents, Puerto Ricans and African Americans are more likely to be exposed to severe stress and to experience post-traumatic stress disorder (PTSD), which has been linked to increased asthma morbidity [3-6,10]. Pituitary adenylate cyclase-activating polypeptide (PACAP) broadly regulates cellular stress responses. In a landmark study, Ressler et al examined the role of the PACAP-PAC1 receptor pathway in PTSD in a cohort of adults with significant exposure to lifetime traumatic events[15**] .In this study, PACAP blood levels were significantly associated with fear responses, PTSD diagnosis and PTSD symptoms in women but not in men. After genotyping 44 single nucleotide polymorphisms (SNPs) in the genes encoding PACAP (ADCYAPI) and PAC1 (ADCYAPIRI), the authors demonstrated a female-specific association between a SNP in a putative estrogen response element within ADCYAPIRI (rs2267735) and fear discrimination, PTSD diagnosis and symptoms, and $A D C Y A P 1 R 1$ messenger RNA expression in human brain. Epigenetic regulation (methylation) of ADCYAPIRI in peripheral blood was also shown to be associated with PTSD in both men and women, raising the issue of whether sex-independent effects of PACAP or SNP rs 2267735 could be demonstrated in a sufficiently large cohort. To complement their findings in humans, the investigators showed induction of ADCYAPIRI mRNA by fear or estrogen replacement in murine models. Taken together, these novel results suggest that alterations in the PACAP-PAC1 receptor pathway underlie abnormal stress responses in PTSD, and that sex-specific effects may be mediated by estrogen regulation. PACAP levels and ADCYAPIRI SNPs may serve as useful biomarkers to better understand the pathogenesis of PTSD and consequences of psychosocial risk exposures and perhaps, the link between this entity and asthma morbidity.

Little is known about the relation between trauma or PTSD and lung function, which can be associated with asthma severity or control. Spitzer et al. examined the relationship between traumatic stress (defined as lifetime exposure to $\geq 1$ traumatic event), with or without PTSD, and lung function measures in 1,772 adults [16]. In a multivariate analysis, PTSD was strongly associated with asthma symptoms but not with $\mathrm{FEV}_{1}$ or $\mathrm{FEV}_{1} / \mathrm{FVC}$. In contrast, traumatic stress was significantly associated with modest reductions in $\mathrm{FEV}_{1}(\sim 34 \mathrm{ml})$ and $\mathrm{FEV}_{1} / \mathrm{FVC}(\sim 6.3 \%)$, adjusting for age, sex, smoking, medication use and other confounders. Because the study was cross-sectional, the temporal relationship between traumatic stress or PTSD and the development of asthma symptoms or lung function abnormalities could not be established. Additional limitations of this study include inadequate power to detect modest 
effects of PTSD on lung function, potential selection bias and use of non-standardized instruments to assess panic attacks and negative emotional states.

Wright et al. conducted a longitudinal study of stressors related to the Iraqi invasion of Kuwait and incident asthma in elderly Kuwaiti civilians[17]. After adjustment for smoking and other potential confounders, subjects who were highly exposed to war stressors had 2.3 times higher odds of asthma than those unexposed $(95 \%$ confidence interval [CI] for hazard ratio $=1.3-3.9$ ). Interpretation of the study findings is limited by potential misclassification of COPD as asthma and residual confounding by access to healthcare.

Socioeconomic status (SES) may also be related to and/or modify the effects of exposure to community violence and psychosocial stress on asthma. Most studies on this topic have focused on children and youth. A recent prospective cohort study of 326 inner-city adult residents with moderate to severe asthma found that stress was significantly correlated with poorer asthma control, poor asthma quality of life and decreased adherence with prescribed medications at baseline and after one year of follow-up [18]. Limitations of this study include inability to exclude "reverse causation" (e.g., if individuals whose asthma is more poorly controlled are also more likely to perceive stress), lack of objective markers of asthma severity or control, and residual confounding by smoking.

\section{Resilience, SES, and Childhood Asthma}

Recent research has focused on individual-level factors that may reduce the impact of stressors related to low SES on asthma morbidity in childhood [19*]. In an observational study of 121 children (ages 9 to 18 years) with physician-diagnosed asthma, those who came from low-SES but engaged in shift-and-persist strategies (e.g., dealing with stressors by reframing them more positively while at the same time persisting in optimistic thoughts about the future) had less asthma inflammation (assessed by eosinophil count and IL-4 levels in peripheral blood) at baseline $(\beta=0.19, \mathrm{P}<.05)$ and less asthma impairment (reduced rescue inhaler use and fewer school absences; $\beta=0.32, \mathrm{P}<.01$ ) after 6 months of follow-up than those from low SES who did not engage in shift-and-persist strategies. Although the study was limited by infrequent follow up (and thus inadequate assessment of physician visits and hospitalizations) and lack of data on medication adherence, its findings suggest that developing approaches to cope with stressors related to SES may help reduce existing asthma disparities in childhood.

\section{Potential Biological Mechanisms}

Experiments in animal models have shown that stress may influence asthma through effects on the immune system. Kang et al. examined the effects of acute and chronic stress on cytokine levels in bronchoalveolar lavage (BAL) fluid following antigen challenge of mice with and without allergic airway inflammation (AAI)[20]. Compared to antigen-challenged mice with AAI but no stress exposure, antigen-challenged mice exposed to acute or chronic stress had significantly higher levels of interleukin 4 (IL-4) but significantly lower levels of interferon gamma (IFN- $\gamma$ ) in BAL fluid. Antigen-challenged mice with AAI that were exposed to acute stress had higher IL-4 and IL-4/IFN- $\gamma$ levels in BAL fluid than those exposed to chronic stress, suggesting that acute stress may increase the risk of asthma exacerbations through enhanced Th2 immune responses.

Stress may modify the effects of environmental exposures on asthma or asthma morbidity. A recent study in rats showed that those exposed to both air pollution (concentrated ambient particles) and stress had higher levels of inflammatory markers, white blood cell counts and worse respiratory and lung function than those exposed only to stress or air pollution[21*]. Overall, the study results suggest that subacute stress may modify the effects of air pollution 
on systemic inflammation and the respiratory system. In a recent population-based study of children, parental stress was associated with increased susceptibility to environmental traffic particulate exposures and significant reductions in $\mathrm{FEV}_{1}[22 *]$.

\section{FAMILY LEVEL}

\section{Prenatal/early-life exposure to stress and asthma morbidity}

For a comprehensive review of the recent literature on early-life exposure to stress and asthma, the reader is referred to recent articles in this journal and elsewhere $[7,11,23,24]$ [25].

Prenatal maternal stress has been associated with increased asthma morbidity in childhood [26,27]. In a cohort study of 557 families in the U.S. predominantly belonging to ethnic minorities, prenatal composite cumulative stress (a score incorporating individual stressors and ecological strains, including housing and neighborhood problems) was associated with altered innate and adaptive immune responses, as assessed by cord blood mononuclear cell (CBMC) cytokines[23**]. In particular, higher prenatal stress was associated with increased IL-8 and TNF- $\alpha$ after microbial stimuli, increased IL-13 after dust mite stimuli and reduced phytohemagglutinin-induced IFN- $\gamma$. Longitudinal follow-up of participants should help elucidate whether the effects of prenatal maternal stress on early-life immune responses leads to an increased risk of asthma or allergic diseases in childhood.

\section{Parenting styles, parental stress and asthma morbidity in childhood}

Much attention has been given to prenatal and early-life exposure to maternal stress on childhood asthma morbidity[28,29], while little is known regarding the influence of paternal psychosocial factors and childhood asthma [11**]. In the first such study of paternal influence, data on indicators of psychosocial stress and asthma morbidity was collected from interviews with fathers and mothers of 678 Puerto Rican twins at ages 1 and 3 years. In a multivariate analysis combining outcomes at ages 1 and 3 years, paternal depression was associated with increased use of oral steroids for asthma, maternal depressive symptoms were associated with higher incidence of asthma diagnosis and increased asthma hospitalizations, and parental (maternal and/or paternal) depression was associated with increased asthma hospitalizations. Further follow-up of this cohort and/or future studies should help characterize the independent and joint effects of paternal and maternal stress on asthma morbidity in childhood.

In a one-year longitudinal study of 224 mothers of children with asthma, Nagano et al. showed that maternal irritation/anger or emotional suppression was associated with greater asthma severity at 1 year in children younger than 7 years. In children 7 years and older, maternal self-centered behavior was associated with greater asthma severity after 1 year of follow-up [30]. Interpretation of the study findings is limited by lack of objective markers of asthma severity or control, no formal testing for an interaction between maternal stress and children's age, and potential residual confounding by baseline asthma severity.

\section{Intimate Partner Violence (IPV) and Childhood Asthma}

Recent studies have examined the relation between maternal intimate partner violence (IPV) and childhood asthma. In a birth cohort study of 3,116 families with an over-representation of non-marital births, chronic IPV was associated with twofold increased odds of physiciandiagnosed asthma at age 3 years [31*]. In an analysis stratified by mother-child activities (MCAs), children whose mothers were exposed to chronic IPV and a low level of MCAs had higher odds of asthma at age 3 years than those exposed to chronic IPV but with a high level of MCAs. In another analysis of data from the same cohort, the investigators report 
modification of the effect of chronic IPV on asthma by living in deteriorated or disarrayed housing, as well as by housing hardship [32]. Although these two studies are limited by potential misclassification of asthma in young children, lack of formal testing for interaction between IPV and either MCAs or housing conditions, and non-correction of results for multiple testing, their findings suggest that intervention efforts targeting both the social and physical environment in the homes of children at risk are more likely to reduce asthma burden than single-target interventions.

\section{COMMUNITY LEVEL}

Exposure to community crime and community violence may influence asthma morbidity [19,33-37]. In a three-year longitudinal study, young children attending low socioeconomic status (SES) schools and living in areas with high crime rates were found to have increased risk for asthma, even after accounting for parental stress, indoor and traffic -related pollution exposure, and neighborhood segregation [13]. Individual factors within the school (e.g., allergen exposure, building characteristics) and community social environment need to be further studied to better understand the mechanisms underlying the observed associations.

Exposure to community violence within low SES settings (a potential social and contextual risk factor for asthma morbidity) continues to warrant examination in light of persistent and growing ethnic disparities in asthma or asthma morbidity [10,34,37-39]. In a large multilevel longitudinal study of children under the age of 10 years in Chicago, community violence was associated with asthma risk after controlling for potential individual- and neighborhood-level confounders. However, community violence and other individual-level factors failed to fully account for the excess asthma burden in African Americans [34*]. In another study of inner-city adults, predominantly African-American women with moderate to severe asthma in Philadelphia, exposure to community violence at baseline was significantly associated with visits to the emergency department or hospitalizations for asthma over 26 weeks of follow-up, even after accounting for ethnicity and household income [37*].

Assessment of macro-level psychosocial risk exposures presents a number of methodological challenges. Recent studies have strengthened our understanding of psychosocial stressors on asthma morbidity by incorporating novel psychosocial exposure variables to create relevant composite measures of policy-oriented housing-related stressors for low-income, urban, racially/ethnically heterogeneous families of young children with respiratory problems in schools [40*]. While cross-sectional in design, this study is novel in its incorporation of diverse social and housing variables into one construct characterizing urban stress as "social pollutant" negatively influencing general and respiratory health.

\section{Intervening to address stress and asthma morbidity}

Studies that assess the impact of interventions to address the harmful influence of stress at the individual, family or community levels are needed [41]. In the first known problemsolving emotional management intervention for childhood asthma, Long et al. showed significant improvement in lung function, perceived stress and depressed mood in children ages 7-12 years recruited from community and school-based samples. While the study was limited by small sample size, this stress-management intervention aimed at improving asthma education, stress reduction, relaxation, coping and problem solving management skills called "I Can Cope" shows promise for implementation in school-based settings [42*].

\section{Conclusions and Future Directions}

Over the last two years, a number of studies have provided valuable insight into the relation between psychosocial factors and asthma morbidity (Table 1). Additional mechanistic 
studies are needed to understand the effect of biological pathways and ecological (biological, individual, family, and community) stress-related influences on asthma and asthma morbidity. Studies using objective biomarkers and objective measures of asthma, asthma control and asthma severity should be conducted in a spectrum of environmental and social settings, thereby providing a comprehensive examination of the complex intersecting relationships of contextual psychosocial stressors upon asthma and asthma morbidity [10]. Furthermore, interventional studies should be conducted to assess the public health implications of alleviating the burden of psychosocial stress on asthma in populations at risk.

Methodological challenges to be addressed in future studies include defining and characterizing psychosocial stressors, and developing biomarkers[43]. The need to carefully define such factors is particularly salient to characterizing stressors effectively within diverse socio-cultural, geographic and ecological settings. Mixed-methods approaches utilized to examine, document and define the relationship and mechanistic and contextual pathways upon asthma morbidity can complement the growing body of population-based research and inform population-based studies guided by community priorities $[36,44]$. Federal guidelines to address chronic disparities in health [45], as well as results from community-based asthma studies, suggest that engaged research approaches, such as community-based participatory research (CBPR) contribute positively to the enhancement of community capacity to address important contextual triggers, reduce environmental hazards and improve the health of community residents [44]. CBPR provides an approach and framework for practitioners, community members and academics to address disparities in health and work in partnership to design, conduct and implement research and to disseminate the findings within affected communities [36,44,46].

As highlighted in this review and other published literature, the relationship between stress and asthma is far from understood. Future research and interventions that integrate a multilevel perspective and resources from clinical, community, public health and policy settings should improve our ability to understand and mitigate the influence of psychosocial stress on asthma morbidity.

\section{Key Points}

- Recent findings suggest and strengthen recognition that stress at the individual, family and community- level influence asthma and asthma morbidity in children and across the lifespan;

- Key new findings illustrate how psychosocial stress may influence asthma through Post Traumatic Stress Disorder (PTSD), pre-and post-natal maternal/ caregiver stress, family and community violence and deprivation influence asthma morbidity;

- Innovative methodologies that document pathways associated with stress at multiple levels, as well as evaluation of potential interventions that mitigate the impact of stress upon asthma morbidity are needed to address persistent disparities in asthma within racial/ethnic minority and economically disadvantaged communities.

\section{Acknowledgments}

Funding for this work was provided by NIH grants HL089990, HL079966, KL2 RR024154 (Clinical Research Scholar). NIH Translational Science Award/NCRR. University of Pittsburgh (CTSA KL2), and Pediatric Environmental Medicine Center, funding provided by The Heinz Endowments. 


\section{REFERENCES}

Articles of particular interest, published within the last two years, have been highlighted as:

- of special interest

•• of outstanding interest

1. Akinbami LJ, Moorman JE, Liu X. Asthma prevalence, health care, use, mortality: United States: 2005-2009. Natl Health Stat Report. 2011:1-14. [PubMed: 21355352]

2. Asher MI, Montefort S, Bjorksten B, Lai CK, Strachan DP, Weiland SK, Williams H. Worldwide time trends in the prevalence of symptoms of asthma, allergic rhinoconjunctivitis, and eczema in childhood: ISAAC Phases One and Three repeat multicountry cross-sectional surveys. Lancet. 2006; 368:733-743. [PubMed: 16935684]

3. Martinez-Taboas A, Canino G, Wang MQ, Garcia P, Bravo M. Prevalence and victimization correlates of pathological dissociation in a community sample of youths. J Trauma Stress. 2006; 19:439-448. [PubMed: 16929499]

4. Canino GJ, Bird HR, Shrout PE, Rubio-Stipec M, Bravo M, Martinez R, Sesman M, Guevara LM. The prevalence of specific psychiatric disorders in Puerto Rico. Arch Gen Psychiatry. 1987; 44:727-735. [PubMed: 3498456]

5. Shrout PE, Canino GJ, Bird HR, Rubio-Stipec M, Bravo M, Burnam MA. Mental health status among Puerto Ricans, Mexican Americans, and non-Hispanic whites. Am J Community Psychol. 1992; 20:729-752. [PubMed: 1302447]

6. Canino G, Shrout PE, Rubio-Stipec M, Bird HR, Bravo M, Ramirez R, Chavez L, Alegria M, Bauermeister JJ, Hohmann A, et al. The DSM-IV rates of child and adolescent disorders in Puerto Rico: prevalence, correlates, service use, the effects of impairment. Arch Gen Psychiatry. 2004; 61:85-93. [PubMed: 14706947]

7. Forno E, Celedon JC. Asthma and ethnic minorities: socioeconomic status and beyond. Curr Opin Allergy Clin Immunol. 2009; 9:154-160. [PubMed: 19326508]

8. Haczku A, Panettieri RA Jr. Social stress and asthma: The role of corticosteroid insensitivity. Journal of Allergy and Clinical Immunology. 2010; 125:550-558. [PubMed: 20153032]

9. Wright RJ, Cohen RT, Cohen S. The impact of stress on the development and expression of atopy. Curr Opin Allergy Clin Immunol. 2005; 5:23-29. [PubMed: 15643340]

10. Wright RJ. Epidemiology of stress and asthma: from constricting communities and fragile families to epigenetics. Immunol Allergy Clin North Am. 2011; 31:19-39. [PubMed: 21094921]

11. Lange NE, Bunyavanich S, Silberg JL, Canino G, Rosner BA, Celedón JC. Parental psychosocial stress and asthma morbidity in Puerto Rican twins. Journal of Allergy and Clinical Immunology. 2011; 127:734-740. e737. [PubMed: 21194742] . **First report of an association between paternal psychosocial stress and increased asthma morbidity in childhood.

12. Bronfenbrenner, $U$. The ecology of human development : experiments by nature and design. Cambridge, Mass.: Harvard University Press; 1979.

13. Shankardass K, Jerrett M, Milam J, Richardson J, Berhane K, McConnell R. Social environment and asthma: associations with crime and No Child Left Behind programmes. J Epidemiol Community Health. 2011; 65:859-865. [PubMed: 21071562]

14. Wright RJ, Suglia SF, Levy J, Fortun K, Shields A, Subramanian S, Wright R. Transdisciplinary research strategies for understanding socially patterned disease: the Asthma Coalition on Community, Environment, and Social Stress (ACCESS) project as a case study. Cien Saude Colet. 2008; 13:1729-1742. [PubMed: 18833350]

15. Ressler KJ, Mercer KB, Bradley B, Jovanovic T, Mahan A, Kerley K, Norrholm SD, Kilaru V, Smith AK, Myers AJ, et al. Post-traumatic stress disorder is associated with PACAP and the PAC1 receptor. Nature. 2011; 470:492. [PubMed: 21350482] . **Landmark study illustrating that PACAP levels and ADCYAP1R1 SNPs may serve as useful biomarkers to further our mechanistic understanding of stress on health (PTSD) 
16. Spitzer C, Koch B, Grabe HJ, Ewert R, Barnow S, Felix SB, Ittermann T, Obst A, Volzke H, Glaser S, et al. Association of airflow limitation with trauma exposure and post-traumatic stress disorder. Eur Respir J. 2011; 37:1068-1075. [PubMed: 20729219]

17. Wright RJ, Fay ME, Suglia SF, Clark CJ, Evans JS, Dockery DW, Behbehani J. War-related stressors are associated with asthma risk among older Kuwaitis following the 1990 Iraqi invasion and occupation. J Epidemiol Community Health. 2010; 64:630-635. [PubMed: 20231738]

18. Wisnivesky JP, Lorenzo J, Feldman JM, Leventhal H, Halm EA. The relationship between perceived stress and morbidity among adult inner-city asthmatics. J Asthma. 2010; 47:100-104. [PubMed: 20100028]

19. Chen E, Strunk RC, Trethewey A, Schreier HM, Maharaj N, Miller GE. Resilience in lowsocioeconomic- status children with asthma: Adaptations to stress. J Allergy Clin Immunol. 2011; 128:970-976. [PubMed: 21824649] . * Psychological response processes that low SES children develop to adapt to stressors may represent practical and effect foundation for reducing disparities in asthma.

20. Kang D-H, Weaver MT. Airway cytokine responses to acute and repeated stress in a murine model of allergic asthma. Psychobiology of Respiration and the Airways. 2010; 84:66-73.

21. Clougherty JE, Rossi CA, Lawrence J, Long MS, Diaz EA, Lim RH, McEwen B, Koutrakis P, Godleski JJ. Chronic Social Stress and Susceptibility to Concentrated Ambient Fine Particles in Rats. Environmental Health Perspectives. 2010; 118:769-775. [PubMed: 20194079] . * Valuable ecological study which supports epidemiologic findings that chronic stress may alter respiratory response to air pollution exposure and influence differential susceptibility to asthma morbidity.

22. Islam T, Urman R, Gauderman WJ, Milam J, Lurmann F, Shankardass K, Avol E, Gilliland F, McConnell R. Parental Stress Increases the Detrimental Effect of Traffic Exposure on Children's Lung Function. American journal of respiratory and critical care medicine. 2011; 184:822-827. [PubMed: 21700914] . *A cross-sectional study showing that parental stress increases potential detrimental effects of traffic-related particulate exposure on childhood FEV 1 .

23. Wright RJ, Visness CM, Calatroni A, Grayson MH, Gold DR, Sandel MT, Lee-Parritz A, Wood RA, Kattan M, Bloomberg GR, et al. Prenatal maternal stress and cord blood innate and adaptive cytokine responses in an inner-city cohort. Am J Respir Crit Care Med. 2010; 182:25-33.

[PubMed: 20194818] . ** Prenatal stress was associated with altered innate and adaptive immune responses indicating that interventions to reduce perinatal immunomodulation related to stress may impact the expression of allergic disease in these children

24. Suglia SF, Staudenmayer J, Cohen S, Enlow MB, Rich-Edwards JW, Wright RJ. Cumulative Stress and Cortisol Disruption among Black and Hispanic Pregnant Women in an Urban Cohort. Psychol Trauma. 2010; 2:326-334. [PubMed: 21423846]

25. Dreger LC, Kozyrskyj AL, HayGlass KT, Becker AB, MacNeil BJ. Lower cortisol levels in children with asthma exposed to recurrent maternal distress from birth. Journal of Allergy and Clinical Immunology. 2010; 125:116-122. [PubMed: 19962747]

26. Kozyrskyj AL, Bahreinian S, Azad MB. Early life exposures: impact on asthma and allergic disease. Curr Opin Allergy Clin Immunol. 2011; 11:400-406. [PubMed: 21772139]

27. Reyes M, Perzanowski MS, Whyatt RM, Kelvin EA, Rundle AG, Diaz DM, Hoepner L, Perera FP, Rauh V, Miller RL. Relationship between maternal demoralization, wheeze, and immunoglobulin E among inner-city children. Annals of Allergy, Asthma \& Immunology. 2011; 107:42-49. e41.

28. Wood RA, Bloomberg GR, Kattan M, Conroy K, Sandel MT, Dresen A, Gergen PJ, Gold DR, Schwarz JC, Visness CM, et al. Relationships among environmental exposures, cord blood cytokine responses, allergy, and wheeze at 1 year of age in an inner-city birth cohort (Urban Environment and Childhood Asthma study). J Allergy Clin Immunol. 2011; 127:913-919. e911e916. [PubMed: 21333343]

29. Sharp LK, Curtis LM, Mosnaim G, Shalowitz MU, Catrambone C, Sadowski LS. The influence of caregiver's psychosocial status on childhood asthma and obesity. Annals of Allergy, Asthma, \& Immunology. 2009; 103:386.

30. Nagano J, Kakuta C, Motomura C, Odajima H, Sudo N, Nishima S, Kubo C. The parenting attitudes and the stress of mothers predict the asthmatic severity of their children: a prospective study. Biopsychosoc Med. 2010; 4:12. [PubMed: 20929533] 
31. Suglia SF, Enlow MB, Kullowatz A, Wright RJ. Maternal intimate partner violence and increased asthma incidence in children: buffering effects of supportive caregiving. Arch Pediatr Adolesc Med. 2009; 163:244-250. [PubMed: 19255392] . * The association of IPV with increased early childhood asthma risk provides an important ecological context for understanding the influence of maternal stress upon childhood asthma, yet illustrates a need for greater understanding of IPV impact on maternal asthma.

32. Franco Suglia S, Duarte CS, Sandel MT, Wright RJ. Social and environmental stressors in the home and childhood asthma. J Epidemiol Community Health. 2010; 64:636-642. [PubMed: 19828512]

33. Shankardass K, Jerrett M, Milam J, Richardson J, Berhane K, McConnell R. Social environment and asthma: associations with crime and No Child Left Behind programmes. Journal of epidemiology and community health. 2011; 65:859-865. [PubMed: 21071562]

34. Sternthal MJ, Jun HJ, Earls F, Wright RJ. Community violence and urban childhood asthma: a multilevel analysis. Eur Respir J. 2010; 36:1400-1409. [PubMed: 20413538] . * Community violence is associated but does not fully explain asthma risk when controlling for individual- and neighborhood-level confounders. Ecologically sensitive public health interventions outside the biomedical model are needed

35. Bacigalupe GF, Takeo, Selk Sabrina, Woo. Meghan Community Violence as Psychosocial Stressor: The Case of Childhood Asthma in Boston. Psychology. 2010; 1:27-34.

36. Gupta R, Ballesteros J, Springston E, Smith B, Martin M, Wang E, Damitz M. The state of pediatric asthma in Chicago's Humboldt Park: a community-based study in two local elementary schools. BMC Pediatrics. 2010; 10:45. [PubMed: 20576150]

37. Apter AJ, Garcia LA, Boyd RC, Wang X, Bogen DK, Ten Have T. Exposure to community violence is associated with asthma hospitalizations and emergency department visits. Journal of Allergy and Clinical Immunology. 2010; 126:552-557. [PubMed: 20816190] . *Among inner-city adults with moderate to severe asthma, exposure to community violence at baseline was associated with increased risk of subsequent severe disease exacerbations

38. Sternthal MJ, Coull BA, Chiu YH, Cohen S, Wright RJ. Associations among maternal childhood socioeconomic status, cord blood IgE levels, and repeated wheeze in urban children. J Allergy Clin Immunol. 2011; 128:337-345. e331. [PubMed: 21704362]

39. Wright RJ. Psychological stress: a social pollutant that may enhance environmental risk. Am J Respir Crit Care Med. 2011; 184:752-754. [PubMed: 21965012]

40. Quinn KK, Jay S, Siddiqi Arjumand, Yeatts Karin B. Stress and the City: Housing Stressors are Associated with Respiratory Health among Low Socioeconomic Status Chicago Children. J Urban Health. 2010; 87:688-702. [PubMed: 20499191] . * Composite multi-level measure of stressors was created highlighting the need for interventions that address individuals and structural-level stressors to reduce health inequities.

41. Lavoie KL, Bouthillier D, Bacon SL, Lemiere C, Martin J, Hamid Q, Ludwig M, Olivenstein R, Ernst P. Psychologic distress and maladaptive coping styles in patients with severe vs moderate asthma. Chest. 2010; 137:1324-1331. [PubMed: 20097803]

42. Long KA, Ewing LJ, Cohen S, Skoner D, Gentile D, Koehrsen J, Howe C, Thompson AL, Rosen RK, Ganley M, et al. Preliminary Evidence for the Feasibility of a Stress Management Intervention for 7- to 12-Year-Olds with Asthma. Journal of Asthma. 2011; 48:162-170. [PubMed: 21332379] . * First intervention that supplements relaxation training with emotional management and asthma specific problem-solving and coping skills training

43. Klinnert MD, Price MR, Liu AH, Robinson JL. Unraveling the Ecology of Risks for Early Childhood Asthma Among Ethnically Diverse Families in the Southwest. American Journal of Public Health. 2002; 92:792-798. [PubMed: 11988449]

44. Parker EA, Chung LK, Israel BA, Reyes A, Wilkins D. Community organizing network for environmental health: using a community health development approach to increase community capacity around reduction of environmental triggers. J Prim Prev. 2010; 31:41-58. [PubMed: 20306137]

45. Koh HK, Graham G, Glied SA. Reducing racial and ethnic disparities: the action plan from the department of health and human services. Health Aff (Millwood). 2011; 30:1822-1829. [PubMed: 21976322] 
46. Edgren KK, Parker EA, Israel BA, Lewis TC, Salinas MA, Robins TG, Hill YR. Community involvement in the conduct of a health education intervention and research project: Community Action Against Asthma. Health Promot Pract. 2005; 6:263-269. [PubMed: 16020621] 


\section{Community-Level factors}

Negative: I ow sodoeconomic stotus (SES), violenoe/violence exposure, community crime, poor housing

Positive: collective efficacy

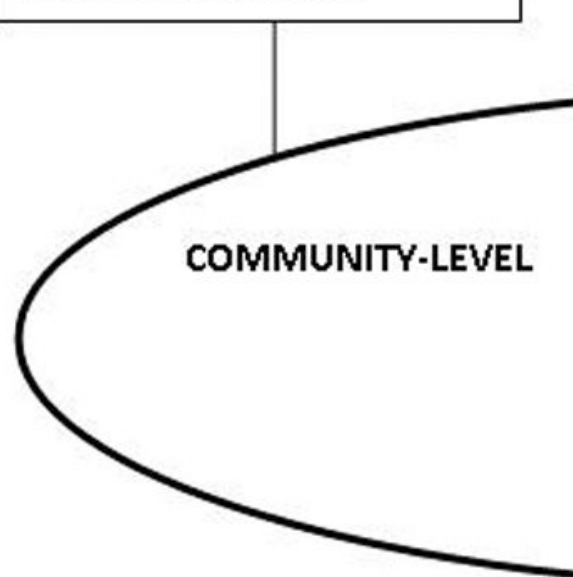

Matemal/Family-Level Factors

Negative: prenatal matemal stress, Inti mate Partner

Violence (IFV), maternal stress, paternal stress, poor housing conditions

Positive: matemal-child interaction and activities

\section{Individual-Level factors}

Negative: PTSD, trauma, low SES, ai pollution, genetic/epi geneticfactors

Positive: stress management, problemsolving and relaxation strategies, shift and persiststrategies, geneti $/$ epigenetic factors

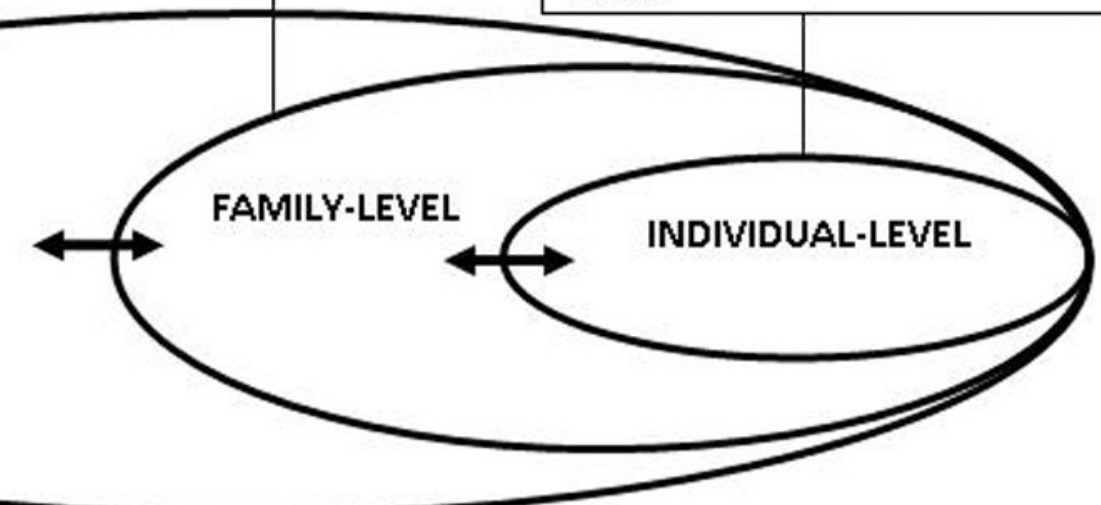

Figure 1.

Ecological framework of the relation between psychosocial stressors and asthma morbidity. 
Table 1

\begin{tabular}{|c|c|c|c|}
\hline Reference & Study design & Main findings & Study limitations \\
\hline Longe et al. [11"“] & $\begin{array}{l}\text { Longitudinal study of } 339 \text { twin } \\
\text { pairs in Puerto Rico, followed } \\
\text { from birth to age } 3 \text { years }\end{array}$ & $\begin{array}{l}\text { Indicators of maternal and paternal } \\
\text { psychosocial stress were associated with } \\
\text { increased asthma morbidity in early childhood }\end{array}$ & $\begin{array}{l}\text { Potential misclassification of asthma } \\
\text { in early childhood; Inability to } \\
\text { adequately exclude 'reverse } \\
\text { causation' (asthma morbidity in the } \\
\text { children leading to increased } \\
\text { parental stress); uncertain } \\
\text { generalizability to nontwins }\end{array}$ \\
\hline $\begin{array}{l}\text { Shankardass et al. } \\
\text { [13] }\end{array}$ & $\begin{array}{l}\text { Prospective multilevel cohort } \\
\text { study of } 2456 \text { children in } 274 \\
\text { Census Tracks within the CHS } \\
\text { cohort }\end{array}$ & $\begin{array}{l}\text { Children attending schools receiving Title } 1 \\
\text { funds and living in areas with higher rates of } \\
\text { larceny crime had an increased risk of asthma }\end{array}$ & $\begin{array}{l}\text { Limited assessment of the school } \\
\text { social environment }\end{array}$ \\
\hline $\begin{array}{l}\text { Ressler et al. } \\
{\left[15^{*}\right]}\end{array}$ & $\begin{array}{l}\text { Cohort study of more than } 1200 \\
\text { highly traumatized adults with } \\
\text { and without PTSD }\end{array}$ & $\begin{array}{l}\text { Alterations in the PACAP-PAC1 receptor } \\
\text { pathway underlie abnormal stress responses in } \\
\text { PTSD }\end{array}$ & $\begin{array}{l}\text { Lack of association between PACAP } \\
\text { blood level and PTSD or fear } \\
\text { responses in men may be due to } \\
\text { limited statistical power due to } \\
\text { insufficient sample size }\end{array}$ \\
\hline Spitzer et al. [16] & $\begin{array}{l}\text { Cross sectional study of } 1772 \\
\text { German adults in the SHIP }\end{array}$ & $\begin{array}{l}\text { PTSD was associated with asthma symptoms } \\
\text { but not with } \mathrm{FEV}_{1} \text { or } \mathrm{FEV}_{1} / \mathrm{FVC} \text {. In contrast, } \\
\text { traumatic stress was associated with modest } \\
\text { reductions in } \mathrm{FEV}_{1} \text { and } \mathrm{FEV}_{1} / \mathrm{FVC}\end{array}$ & $\begin{array}{l}\text { Inability to exclude reverse } \\
\text { causation; potential selection bias }\end{array}$ \\
\hline Wright et al. [17] & $\begin{array}{l}\text { Longitudinal study of war } \\
\text { stressors and asthma in Kuwaiti } \\
\text { adults }\end{array}$ & $\begin{array}{l}\text { A high level of war-related stress exposure } \\
\text { was associated with an approximately two- } \\
\text { fold increased risk of asthma }\end{array}$ & $\begin{array}{l}\text { Potential misclassification of asthma; } \\
\text { residual confounding by access to } \\
\text { healthcare }\end{array}$ \\
\hline $\begin{array}{l}\text { Wisnivesky et al. } \\
\text { [18] }\end{array}$ & $\begin{array}{l}\text { Prospective study of } 326 \text { adults } \\
\text { with moderate to severe asthma } \\
\text { in New York City and New } \\
\text { Jersey }\end{array}$ & $\begin{array}{l}\text { Higher perceived stress associated with } \\
\text { decreased asthma control, medication } \\
\text { adherence and quality of life }\end{array}$ & $\begin{array}{l}\text { Inability to exclude reverse } \\
\text { causation; residual confounding by } \\
\text { smoking; lack of objective measures } \\
\text { of asthma control or severity (e.g. } \\
\text { lung function) }\end{array}$ \\
\hline Chen et al. [19] & $\begin{array}{l}\text { Prospective study of } 121 \\
\text { children aged 9-18 years with a } \\
\text { physician's diagnosis of } \\
\text { asthhma }\end{array}$ & $\begin{array}{l}\text { Children who came from low SES but } \\
\text { engaged in shift-and-persist strategies had less } \\
\text { asthma inflammation at baseline and less } \\
\text { asthma impairment after } 6 \text { months of follow- } \\
\text { up than those from low SES who did not } \\
\text { engage in shift-and-persist strategies }\end{array}$ & $\begin{array}{l}\text { Infrequent follow-up; lack of data on } \\
\text { medication adherence }\end{array}$ \\
\hline $\begin{array}{l}\text { Kang and Weaver } \\
{[20]}\end{array}$ & $\begin{array}{l}\text { Murine study of the effects of } \\
\text { acute and chronic stress on } \\
\text { cytokine levels in BAL Fluid } \\
\text { following antigen challenge of } \\
\text { mice with and without AAI }\end{array}$ & $\begin{array}{l}\text { Compared with antigen-challenged mice with } \\
\text { AAI but no stress exposure, antigen } \\
\text { challenged mice exposed to acute or chronic } \\
\text { stress had significantly higher levels of IL-4 } \\
\text { but significantly lower levels of IFN- } \gamma \text { in } \\
\text { BAL fluid. Antigen-challenged mice with } \\
\text { AAI that were exposed to acute stress had } \\
\text { higher IL-4 and IL-4/IFN- } \gamma \text { levels in BAL } \\
\text { fluid than those exposed to chronic stress }\end{array}$ & $\begin{array}{l}\text { Lack of assessment of cells involved } \\
\text { in immune responses; uncertainty } \\
\text { regarding what constitutes chronic } \\
\text { stress in murine models, as well as } \\
\text { generalizability of findings in murine } \\
\text { models to humans }\end{array}$ \\
\hline $\begin{array}{l}\text { Clougherty et al. } \\
{\left[21^{*}\right]}\end{array}$ & $\begin{array}{l}\text { Study of the effects of stress } \\
\text { and exposure to Fine CAPs on } \\
\text { biomarkers of inflammation in } \\
24 \text { rats }\end{array}$ & $\begin{array}{l}\text { Rats exposed to both CAPs and stress had } \\
\text { higher levels of inflammatory markers, white } \\
\text { blood cell counts and worse respiratory and } \\
\text { lung function than those exposed only to } \\
\text { stress or air pollutions }\end{array}$ & $\begin{array}{l}\text { Small sample size; uncertain } \\
\text { generalizability of results to humans }\end{array}$ \\
\hline
\end{tabular}

\begin{tabular}{|llll|}
\hline Table 1-b Recent studies of psychosocial stress and asthma morbidity & \\
\hline $\begin{array}{l}\text { Islam } \text { et al. } \\
{\left[22^{*}\right]}\end{array}$ & $\begin{array}{l}\text { Cross-sectional study or 1399 } \\
\text { children of school age in } \\
\text { Southern California }\end{array}$ & $\begin{array}{l}\text { Parental stress was associated with increased } \\
\text { susceptibility to detrimental effects of traffic } \\
\text { particulate exposures on FEV }\end{array}$ & $\begin{array}{l}\text { Potential misclassification of traffic- } \\
\text { related particulate exposures; utilization } \\
\text { of parental/household stress measure as } \\
\text { proxy for child stress }\end{array}$ \\
\hline $\begin{array}{l}\text { Wright } \text { et al. } \\
{\left[23^{*}\right]}\end{array}$ & $\begin{array}{l}\text { Birth cohort study of 557 } \\
\text { mother-child pairs from the } \\
\text { Urban Environment and } \\
\text { Childhood Asthma Study }\end{array}$ & $\begin{array}{l}\text { Prenatal composite cumulative stress was } \\
\text { associated with altered innate and adoptive } \\
\text { immune responses, as assessed by CBMC } \\
\text { cytokines }\end{array}$ & $\begin{array}{l}\text { Longitudinal follow-up of children needed } \\
\text { to assess true impact of stres on } \\
\text { development of allergy and asthma }\end{array}$ \\
\hline
\end{tabular}


Table 1-b Recent studies of psychosocial stress and asthma morbidity

\begin{tabular}{|c|c|c|c|}
\hline $\begin{array}{l}\text { Nagano at al. } \\
\text { [30] }\end{array}$ & $\begin{array}{l}\text { Prospective study of } 223 \\
\text { children with asthma (ages } 2- \\
12 \text { years) and their mothers }\end{array}$ & $\begin{array}{l}\text { After } 1 \text { year of follow-up, maternal irritation/ } \\
\text { anger or emotional suppression was associated } \\
\text { with greater asthma severity in children } \\
\text { younger than } 7 \text { years. In children } 7 \text { years and } \\
\text { older, maternal self-centered behavior was } \\
\text { associated with greater asthma severity }\end{array}$ & $\begin{array}{l}\text { Lack of objective markers of asthma } \\
\text { severity or control; no formal testing of an } \\
\text { interaction between maternal stress and } \\
\text { children's age; potential residual } \\
\text { confounding by baseline asthma severity }\end{array}$ \\
\hline $\begin{array}{l}\text { Suglia et al. } \\
\text { [31] }\end{array}$ & $\begin{array}{l}\text { Birth cohort study of } 3116 \\
\text { families with an over- } \\
\text { representation of nonmarital } \\
\text { births }\end{array}$ & $\begin{array}{l}\text { Chronic IPV was associated with two-fold } \\
\text { increased odds of physician-diagnosed asthma } \\
\text { at age } 3 \text { years. In an analysis stratified by } \\
\text { MCAs, children whose mothers were exposed } \\
\text { to chronic IPV and a low level of MCAs had } \\
\text { higher odds of asthma at age } 3 \text { years than } \\
\text { those exposed to chronic IPV but with a high } \\
\text { level of MCAs }\end{array}$ & $\begin{array}{l}\text { Potential misclassification of asthma in } \\
\text { young children; lack of formal testing for } \\
\text { interaction between IPV and MCAs; } \\
\text { noncorrection of results for multiple } \\
\text { testing; self report of care-giving } \\
\text { behaviors and IPV experience }\end{array}$ \\
\hline $\begin{array}{l}\text { Suglia et al. } \\
\text { [32] }\end{array}$ & $\begin{array}{l}\text { Birth cohort study of } 3116 \\
\text { families with on over- } \\
\text { representation of nonmarital } \\
\text { births }\end{array}$ & $\begin{array}{l}\text { Modification of the effect of chronic IPV by } \\
\text { living in deteriorated or disarrayed housing, as } \\
\text { well as, by housing hardship }\end{array}$ & $\begin{array}{l}\text { Cross-sectional analysis; potential } \\
\text { misclassification of asthma in young } \\
\text { children; lack of formal testing for } \\
\text { interaction between IPV and disarrayed } \\
\text { housing/housing hardship; noncorrection } \\
\text { of results for multiple testing }\end{array}$ \\
\hline $\begin{array}{l}\text { Sternthal et al. } \\
{\left[34^{*}\right]}\end{array}$ & $\begin{array}{l}\text { Longitudinal multilevel study } \\
\text { of } 207 \text { children aged } 0-9 \\
\text { years in Chicago }\end{array}$ & $\begin{array}{l}\text { Community violence was associated with } \\
\text { asthma risk after controlling for potential } \\
\text { individual-level and neighborhood-level } \\
\text { confounders. However, community violence } \\
\text { and other individual-level factors failed to } \\
\text { fully account for the excess asthma burden in } \\
\text { African Americans }\end{array}$ & $\begin{array}{l}\text { Limited data on other contextual stressors } \\
\text { (e.g. other stressful life events, racism, } \\
\text { housing); potential misclassification of } \\
\text { asthma; lack of objective measures of } \\
\text { lung function or allergy }\end{array}$ \\
\hline $\begin{array}{l}\text { Apter } \text { et al. } \\
{\left[37^{*}\right]}\end{array}$ & $\begin{array}{l}\text { Prospective longitudinal } \\
\text { study of } 397 \text { inner-city adults } \\
\text { with moderate to severe } \\
\text { asthma seen at the emergency } \\
\text { department }\end{array}$ & $\begin{array}{l}\text { Participants exposed to community violence } \\
\text { had increased odds of visits to the emergency } \\
\text { department and hospitalizations for asthma }\end{array}$ & $\begin{array}{l}\text { Self-reported measure of exposure to } \\
\text { community violence; generalizability of } \\
\text { findings to other adults with asthma is } \\
\text { uncertain }\end{array}$ \\
\hline $\begin{array}{l}\text { Quinn et al. } \\
\text { [40"] }\end{array}$ & $\begin{array}{l}\text { Cross-sectional study of } 682 \\
\text { children diagnosed and } \\
\text { undiagnosed with asthma in } \\
\text { Chicago }\end{array}$ & $\begin{array}{l}\text { Housing stressors were significantly } \\
\text { associated with reduced exercise tolerance, } \\
\text { unplanned medical visits and nocturnal } \\
\text { awakenings due to asthma }\end{array}$ & $\begin{array}{l}\text { Potential misclassification of asthma, } \\
\text { nonvalidated measure of household stress; } \\
\text { lack of objective measures of asthma } \\
\text { severity or control }\end{array}$ \\
\hline
\end{tabular}

Table 1-c Recent studies of psychosocial stress and asthma morbidity

Long et al. [42"] Interventional study in 18 children $\quad$ A problem-solving emotional management $\quad$ Small sample size; limited (ages 7-12 years) with asthma intervention led to significant improvement duration of intervention and in lung function, perceived stress and follow-up depressed mood

AAI, allergic airway inflammation; BAL, bronchoalveolor lavage; CAP, concentrated ambient particles; CBMC, cord blood mononuclear cell; CHS, Children's Health Study; IFN, Interferon; IPV intimate partner violence; MCA, mother-child activities; PACAP, Pituitary Adenylate Cyclase-Activating Polypeptide; PTSD, Posttraumatic Stress Disorder; SES, Socioeconomic status; SHIP, Study of Health in Pomerania. 